\title{
Różnorodność kulturowa uczniów wyzwaniem dla współczesnej szkoły
}

KEY WORDS

cultural diversity, migration, refugees, school

\begin{abstract}
Badowska Mariola, Różnorodność kulturowa uczniów wyzwaniem dla współczesnej szkoły [Cultural Diversity of Students Is a Challenge for Contemporary of the School]. Kultura - Społeczeństwo - Edukacja nr 1(7), 2015, Poznań 2015, pp. 179-192, Adam Mickiewicz University Press. ISBN 978-83-232-2944-5. ISSN 2300-0422

The increasing waves of migration mean that naturally comes to the interpenetration of cultures and the phenomenon of cultural diversity. Increasing real multiculturalism in Polish schools contributes to the necessity of making changes in the education system through the creation of new educational programs geared to the diversity and preparation of teaching staff, whose mission is to support and integrate culturally diverse students in the life of the school community.

Effective work that allows the inclusion of students in the school environment, requires of teaching staff not only knowledge of the principles of pedagogy inclusion, but also a high level of intercultural competence, knowledge of the issues of migration, acculturation processes and the accuracy of acculturation strategies, as well as the specifics of the phenomenon of refugees and their traumatic experiences.
\end{abstract}

W procesie wychowania bardzo istotny wpływ na ukształtowanie nawyków dzieci i młodzieży mają nauczyciele i pedagodzy. Nie chodzi tutaj tylko o formalne sposoby oddziaływania na wychowanków, ale również o postawy dorosłych wobec otaczającego świata (Przetacznik-Gierowska, Włodarski, 1994: 86). Na wczesnym etapie rozwoju dzieci ich postawy i nawyki kreowane są poprzez naśladowanie innych, więc istotne jest, aby mogły one czerpać pozytywne wzorce zachowań na drodze do dorosłości, by w ten sposób rozwijać pożądane jednostkowo i społecznie cechy i kompetencje, na które składa się wiedza, umiejętności, postawy umożliwiające pełne i aktywne uczestnictwo w życiu osobistym, społecznym i zawodowym. 


\section{Zadania kadry pedagogicznej w warunkach różnorodności kulturowej}

Umiejętność współpracy, tolerancji, poszanowania odmienności jest szczególnie pożądana ze względu na wzrastającą różnorodność kulturową we współczesnych społeczeństwach, która jest skutkiem zwiększonej mobilności. Jednym z rejonów atrakcyjnych dla migrantów jest kontynent europejski, a zwłaszcza kraje należące do Unii Europejskiej (chociaż nie wszystkie w jednakowym stopniu), do których migrują nie tylko osoby chcące znaleźć lepsze warunki pracy, ale również osoby poszukujące bezpiecznego schronienia ze względu na zagrożenie życia lub zdrowia w kraju ogarniętym konfliktami zbrojnymi. Współczesne migracje charakteryzuje stosunkowo wysoki udział rodzin z dziećmi, co przekłada się na konieczność podejmowania przez kraje przyjmujące działań wspierających umożliwiających imigrantom adaptację $\mathrm{w}$ nowym środowisku. Jak wskazują badacze $\mathrm{z}$ krajów $\mathrm{o}$ większym doświadczeniu $\mathrm{w}$ tej dziedzinie, pierwszą i najważniejszą agencją państwową wspomagającą procesy inkluzji dzieci imigrantów i ich rodzin jest szkoła, która powinna stwarzać przyjazne środowisko w procesach kształcenia, wychowania i adaptacji (zob. Heckmann, 2008). To od niej w dużej mierze zależy, jakie postawy będą prezentowały dzieci wobec otaczającego świata i innych ludzi (Gundara, 2000: 10-14).

Jak podkreślono w Zielonej Księdze Komisji Europejskiej, szkoły muszą odgrywać znaczącą rolę w tworzeniu społeczeństwa włączającego, gdyż stanowią dla młodych ludzi najlepsze miejsce do wzajemnego poznania się i wzajemnego szacunku (Komisja Europejska, 2008: 3).

Podejmowane przez nauczycieli i pedagogów działania powinny więc mieć charakter oddziaływań integracyjnych, dzięki którym dziecko pochodzące z innej kultury będzie włączane w środowisko klasy i szkoły. Poprzez takie działania pobudzone zostaną procesy tworzenia heterogenicznej kulturowo wspólnoty wykorzystującej potencjał wszystkich jednostek, które w przyszłości będą tworzyły wspólnotę dorosłych obywateli.

Elementem przyczyniającym się do kreowania właściwych postaw obywatelskich i otwartości wobec innych jest odpowiednio przygotowana kadra pedagogiczna.

W odpowiedzi na zwiększającą się różnorodność kulturową uczniów grupa robocza powołana przez Komisję Europejską zwróciła uwagę na konieczność posiadania przez nauczycieli nowych kompetencji, do których zaliczyła m.in. umiejętność pracy w wielokulturowej klasie, komunikację i wrażliwość międzykulturową, uwrażliwienie na kwestie kulturowe, umiejętność zarządzania konfliktami, świadomość procesów migracyjnych (Komisja Europejska, 2005). Samo 
pojęcie „kompetencje” nie jest jednoznaczne, ale ogólnie odnosi się ono do „potencjału” i „możliwości” - opartych na wiedzy, umiejętnościach, doświadczeniu i działaniu danej osoby (Sielatycki, 2014).

Specyfika doświadczeń uczniów odmiennych kulturowo wymaga od kadry pedagogicznej umiejętności diagnozowania ich potrzeb i problemów, podejmowania oddziaływań terapeutycznych pomagających skutecznie radzić sobie ze stresem towarzyszącym migracji i adaptacji do warunków kraju przyjmującego oraz wspomagania akulturacji i społecznej integracji, aby zapobiegać niepowodzeniom szkolnym i wykluczeniu społecznemu tej kategorii uczniów.

W warunkach zróżnicowania kulturowego niezbędne staje się kształtowanie wiedzy o równości i prawach człowieka, a także kreowanie postaw wzajemnego szacunku, tolerancji i dialogu, aby wspomagać proces integracji środowiska szkolnego i rozwoju więzi międzygrupowej poprzez korygowanie stereotypów oraz zwalczanie uprzedzeń, ksenofobii i etnocentryzmu.

Wiktor Rabczuk podkreśla, że w szkole przyjmującej dzieci imigranckie należy realizować międzykulturowe podejście w pracy dydaktyczno-wychowawczej, określane jako ogół praktyk edukacyjnych, których celem jest propagowanie szacunku i wzajemnego zrozumienia między uczniami bez względu na przynależność kulturową, etniczną i religijną (Rabczuk, 2007: 90).

Mający pod swoją opieką dzieci pochodzące $\mathrm{z}$ innych kultur powinni mieć ogólne pojęcie na temat wpływu kultury na zachowanie i mentalność jednostki, tj. wartości, motywacje, przekonania, światopogląd, style myślenia, percepcje, zachowania społeczne, konformizm, agresja, stosunek do osób starszych i płci odmiennej, wyrażanie emocji i potrzeb (zob. Boski, 2009).

Przekazywanie wiedzy na temat różnic kulturowych i ich wpływu na sposoby widzenia świata, interpretacji ludzkich zachowań, strategii uczenia się, wyrażania emocji lub umiejętności reagowania na zachowania przedstawicieli innych kultur, zapobieganie postawom etnocentryzmu i ksenofobii, powinny stanowić istotny element w kształceniu przyszłej kadry pedagogicznej. Wzajemne wzbogacanie poprzez kontakt i dialog międzykulturowy jednak jak dotąd nie stanowi powszechnego składnika kształcenia zawodowego przyszłych nauczycieli, pedagogów i psychologów (Borzykowski, Grzymała-Moszczyńska, 2013: 22). Dotychczasowe próby zwrócenia uwagi na konieczność wprowadzania do programów kształcenia akademickiego edukacji międzykulturowej jako elementu rozwijającego kompetencje międzykulturowe przyszłej kadry pedagogicznej nie znalazły akceptacji ze strony decydentów. W dalszym ciągu, pomimo wytycznych unijnych, nie dostrzegają oni potrzeby rozwijania tych umiejętności (zob. Rezolucja, 2009) i stale wzrastającej liczby uczniów pochodzących z innych kręgów kulturowych w polskich placówkach edukacyjnych. 
Obecność uczniów imigranckich stawia przed kadrą pedagogiczną nowe zadania, gdyż wymaga od nich podejmowania działań uwzględniających różnorodność i indywidualne potrzeby wszystkich uczniów, a zarazem stosowania metod integrujących ułatwiających dzieciom wzajemne poznanie i uczenie się oparte na współpracy. Nauczyciele i pedagodzy mający na terenie swoich placówek uczniów cudzoziemskich powinni stosować odpowiednie formy działań wspierających. Aby te działania podejmować, konieczna jest wiedza o procesach adaptacji do nowych warunków życia oraz o specyfice uczniów; ich pochodzeniu, aktualnych problemach, sytuacji rodzinnej, statusie pobytu, kulturze, religii, doświadczeniach edukacyjnych, zdolnościach, aspiracjach itp.

\section{Procesy adaptacji do nowego środowiska}

Emigracja do innego kraju zawsze wiąże się z wieloma problemami i barierami, które trzeba przezwyciężyć, zanim jednostka będzie w stanie w miarę normalnie funkcjonować w nowym środowisku społecznym i kulturowym. Im większy dystans kulturowy (język, normy, zwyczaje) i zmiany związane $\mathrm{z}$ warunkami życia (warunki klimatyczne, miejsce zamieszkania, zwyczaje żywieniowe, interakcje społeczne, zdrowie, doświadczenie migracyjne), tym trudniej jednostce pokonywać poszczególne fazy szoku kulturowego (Grzymała-Moszczyńska, 1998: 42). Szok kulturowy jest tu spostrzegany jako szczególna forma doświadczania zmiany środowiska społecznego, powodującego zaburzenie funkcjonowania psychosomatycznego, wywołane przedłużającym się kontaktem $\mathrm{z}$ odmienną, nieznaną kulturą, dostrzeżeniem istotnych różnic funkcjonowania we własnej i nowej kulturze oraz towarzyszącymi temu odkryciu stanami lęku i dezorientacji. Ma to miejsce zwłaszcza w początkowym okresie pobytu w nowym kraju, często wiąże się z ogromnym obciążeniem psychicznym i fizycznym; dezorientacja, irytacja, agresja, ból, które z czasem ustępują i przeradzają się w zdolność do rozumienia otoczenia i adekwatnego reagowania na bodźce i sytuacje.

W zależności od uzyskiwanego wsparcia lub jego braku ze strony przedstawicieli kraju przyjmującego proces edukacyjno-rozwojowy może mieć zarówno negatywne, jak i pozytywne konsekwencje.

Niezależnie od przyczyn migracji wszystkie osoby migrujące przechodzą ten trudny etap adaptacji, doświadczają problemów wykorzenienia i konieczności dostosowania się do nowych warunków. Poszczególne kategorie imigrantów mogą jednak doświadczać dodatkowych problemów. Imigranci nielegalni żyją w ciągłym poczuciu zagrożenia deportacją, a więc lękiem przed identyfikacją i konsekwencjami rozpoznania. Migranci czasowi nie identyfikują się z miejscem 
pobytu i nie są skłonni uczyć się nowego języka i kultury. Repatrianci natomiast (formalnie uznawani za obywateli polskich) mają problemy z ukształtowaniem własnej tożsamości ze względu na dostrzegane przez otoczenie i nich samych odmienności wynikającej np. z niedostatecznej znajomości języka polskiego i innych dotychczasowych wzorów codziennego życia (Badowska, 2011: 177). Kategorią specyficzną i sprawiającą szczególne trudności w diagnozowaniu potrzeb i problemów dziecka są uchodźcy (Grzymała-Moszczyńska, 2000). Doświadczają oni destabilizacji dotychczasowego życia w wyniku rozprzestrzeniania się konfliktów zbrojnych, prześladowań lub klęsk żywiołowych. Dotychczasowe środowisko, spostrzegane jako bezpieczne, zmienia się w pełne traumatycznych przeżyć miejsce, często eksponujące przemoc, której świadkiem lub co gorsza uczestnikiem staje się samo dziecko. Okresem obfitującym w urazy psychiczne i fizyczne jest także faza ucieczki do innego kraju. W tym okresie dziecko doświadcza licznych deprywacji, styka się z osobami zagrażającymi jego bezpieczeństwu, życiu i zdrowiu, bywa świadkiem, ofiarą lub uczestnikiem aktów wykorzystania i przemocy. Niejednokrotnie traci rodzinę lub zostaje z nią rozdzielone albo staje się osobą odpowiedzialną za jej słabszych członków. Samo dotarcie do kraju pierwszego azylu również jest trudnym etapem, proces rejestracji i orzeczenia statusu uchodźcy trwa wiele miesięcy, pobyt $\mathrm{w}$ ośrodkach recepcyjnych i oczekiwanie na decyzję władz również odciska swoje piętno na psychice dziecka. Traumatyczne przeżycia i doświadczenia skutkują zmianami $\mathrm{w}$ funkcjonowaniu, których konsekwencją są zaburzenia psychofizyczne w wyniku reakcji psychologicznych. Wszystkie traumatyczne doświadczenia powodują poważne zakłócenia w codziennym funkcjonowaniu jednostki.

Do najczęstszych i najlepiej opisanych problemów funkcjonowania dzieci z doświadczeniem uchodźczym, zaliczają się: zespół przewlekłego stresu pourazowego (PTSD - post-traumatic stress disorder), stres walki (stres bojowy), syndrom sztokholmski oraz syndrom ocalonych (Grzymała-Moszczyńska, 2000: 81; por. Januszewska, 2010: s. 46-86). W konsekwencji traumatycznych przeżyć najczęściej jednostka odczuwa przerażenie i bezradność. Towarzyszą temu natrętne myśli, wspomnienia, sny, nagłe emocje, strach, często pojawia się odrętwienie czyli spadek aktywności fizycznej i psychicznej, ból fizyczny trudny do zdiagnozowania, albo symptomy stałego pobudzenia towarzyszące ciągłemu odtwarzaniu lub unikaniu myśli o traumatycznych doświadczeniach tj. drażliwość, wybuchy gniewu, nadwrażliwość na bodźce zewnętrzne, trudności z koncentracją, napady panicznego lęku (Grzymała-Moszczyńska, 2000: 80; por. Januszewska, 2010: 74-76; Krzywicka, 2007: 126).

Kompetentna ewaluacja potrzeb, zachowań i problemów oraz będące jej konsekwencją efektywne oddziaływania wspomagające są $\mathrm{w}$ stanie umożliwić 
uchodźcy powrót do zdrowia i odzyskać stan równowagi. Jednym z najistotniejszych elementów wpływających na poprawę kondycji psychicznej i fizycznej jednostki przezwyciężającej skutki traumy jest więź dająca poczucia bezpieczeństwa. Dziecko doświadczające bliskich więzi z rodzicami lub opiekunami jest $\mathrm{w}$ stanie skutecznie walczyć ze stresem. Istotną rolę odgrywają także jego indywidualne cechy, jak np. umiejętność rozwiązywania problemów i pozytywne myślenie. Jednakże niezależnie od indywidualnych cech, najważniejsze jest odpowiednie wsparcie społeczne, które $\mathrm{w}$ znaczący sposób wpływa na procesy zwalczania skutków traumatycznych przeżyć (Lis-Turlejska, 1998: 104-109).

$\mathrm{W}$ przypadku pozostawienia takiej osoby samej sobie proces ten trwa bardzo długo lub zaburzenia te wciąż mogą się pogłębiać.

\section{Prezentacja wyników badań}

W okresie od kwietnia do grudnia 2012 roku przeprowadziłam badania ankietowe wśród nauczycieli i pedagogów pracujących w 20 warszawskich szkołach, do których uczęszczały dzieci cudzoziemskie. W badaniu udział wzięło 193 nauczycieli i 28 pedagogów szkolnych (199 kobiet i 22 mężczyzn).

Podjęte przeze mnie badania miały na celu między innymi rozpoznanie wybranych aspektów wiedzy nauczycieli i pedagogów na temat specyfiki powierzonych ich opiece dzieci pochodzenia imigranckiego.

Dla potrzeb niniejszych badań sformułowane zostały następujące pytania badawcze:

1. Jaka jest wiedza badanych na temat różnic kulturowych i ich znaczenia dla funkcjonowania dziecka w szkole?

2. Jaka jest wiedza badanych na temat specyfiki kulturowej/sytuacyjnej powierzonych ich opiece dzieci cudzoziemskich?

3. Jaka jest wiedza badanych na temat specyficznych problemów uchodźców i imigrantów?

Wiedza badanych na temat różnic kulturowych i ich znaczenia dla funkcjonowania dziecka w szkole

Chcąc dokonać diagnozy poziomu wiedzy badanych odnośnie różnic kulturowych i znaczenia kultury dla funkcjonowania dziecka w szkole, poprosiliśmy, aby wskazali oni, które z przedstawionych obszarów mają istotny wpływ na kształtowanie się kompetencji ważnych z punktu widzenia procesów dydaktycznych oraz społecznego funkcjonowania dziecka (tab. 1). 
Tabela 1. Wiedza badanych na temat różnic kulturowych i ich znaczenia dla funkcjonowania dziecka w szkole. Źródło: opracowanie własne

\begin{tabular}{|l|c|c|c|c|c|c|}
\hline \multirow{2}{*}{ Obszar wpływu określany jako istotny } & \multicolumn{3}{|c|}{ Stanowisko } & \multicolumn{2}{c|}{ Ogółem } \\
\cline { 2 - 8 } & \multicolumn{2}{|c|}{ nauczyciel } & \multicolumn{2}{|c|}{ pedagog } & \multicolumn{2}{c|}{} \\
\cline { 2 - 8 } & {$[\mathrm{N}]^{\star}$} & {$[\%]$} & {$[\mathrm{N}]^{* *}$} & {$[\%]$} & {$[\mathrm{N}]$} & {$[\%]$} \\
\hline Styl komunikowania się & 179 & 95,7 & 26 & 92,9 & 205 & 95,3 \\
\hline Zachowania społeczne & 173 & 92,5 & 28 & 100,0 & 201 & 93,5 \\
\hline Stosunek do płci odmiennej & 171 & 91,4 & 28 & 100,0 & 199 & 92,5 \\
\hline Stosunek do nauczycieli & 163 & 87,2 & 28 & 100,0 & 191 & 88,8 \\
\hline Styl uczenia się & 165 & 88,2 & 22 & 78,6 & 187 & 87,0 \\
\hline Stosunek do obowiązków szkolnych & 161 & 86,1 & 26 & 92,9 & 187 & 87,0 \\
\hline Poszanowanie norm społecznych & 159 & 85,0 & 24 & 85,7 & 183 & 85,1 \\
\hline Potrzeby poznawcze & 161 & 86,1 & 22 & 78,6 & 183 & 85,1 \\
\hline Motywacja do nauki & 155 & 82,9 & 26 & 92,9 & 181 & 84,2 \\
\hline Agresywność & 133 & 71,1 & 24 & 85,7 & 157 & 84,0 \\
\hline Pilność & 155 & 82,9 & 22 & 78,6 & 177 & 82,3 \\
\hline Potrzeby emocjonalne & 147 & 78,6 & 22 & 78,6 & 169 & 78,6 \\
\hline Zdolność uczenia się & 116 & 62,0 & 14 & 50,0 & 130 & 60,5 \\
\hline Inteligencja & 116 & 62,0 & 4 & 14,3 & 120 & 55,8 \\
\hline
\end{tabular}

$\mathrm{N}^{*}$ - liczba nauczycieli, którzy udzielili odpowiedzi $=187, \mathrm{~N}^{* *}-$ liczba pedagogów, którzy udzielili odpowiedzi $=28$

W grupie nauczycieli 6 respondentów nie udzieliło odpowiedzi. Pozostali badani nauczyciele i pedagodzy ogólnie mieli dobre rozeznanie w znaczeniu czynników kulturowych dla funkcjonowania uczniów, do których zaliczono styl komunikowania się (95\%), ogólnie pojmowane zachowania społeczne oraz postawy wobec dorosłych i płci przeciwnej (93\%), stosunek do obowiązków szkolnych, styl uczenia się (87\%) i motywację do nauki (84\%). Natomiast znaczna część badanych wyraźnie przeceniała wpływ czynników kulturowych na potrzeby poznawcze (85\%), które są naturalną potrzebą rozwojową dzieci ze wszystkich kręgów kulturowych, wpływ kultury na inteligencję (56\%), uznawaną jako cecha wrodzona niezależnie od kultury oraz zdolność uczenia się (60\%), która wiąże się nie tylko $\mathrm{z}$ inteligencją, ale również $\mathrm{z}$ funkcjami pamięci, zdolnością koncentracji, analizy wzrokowej i słuchowej oraz stabilnością emocjonalną.

Tendencję do przeceniania roli kultury w kształtowaniu zdolności uczenia się i inteligencji uczniów częściej wykazywali nauczyciele niż pedagodzy szkolni. Powierzchowność poczynionych w tym względzie obserwacji nie pozwala dokładniej określić, z czego wynika tak wysoki odsetek wskazań nauczycieli na 
takie uwarunkowania (zwłaszcza na inteligencję 62\%). Wskazuje jednak na potrzebę podjęcia dodatkowych badań w tym właśnie zakresie.

Wiedza badanych na temat specyfiki kulturowej/sytuacyjnej powierzonych ich opiece dzieci cudzoziemskich

Badania pokazują, że ogólnie respondenci nie są szczególnie zainteresowani sytuacją swoich podopiecznych (tab. 2).

Tabela 2. Wiedza badanych na temat specyfiki kulturowej i aktualnej sytuacji uczniów cudzoziemskich. Źródło: opracowanie własne

\begin{tabular}{|c|c|c|c|c|c|c|}
\hline \multirow{3}{*}{$\begin{array}{l}\text { Zakres wiedzy określany } \\
\text { jako dobry }\end{array}$} & \multicolumn{4}{|c|}{ Stanowisko } & \multirow{2}{*}{\multicolumn{2}{|c|}{ Ogółem }} \\
\hline & \multicolumn{2}{|c|}{ nauczyciel } & \multicolumn{2}{|c|}{ pedagog } & & \\
\hline & {$[\mathrm{N}]^{*}$} & {$[\%]$} & {$[\mathrm{N}]^{* *}$} & {$[\%]$} & {$[\mathrm{N}]$} & {$[\%]$} \\
\hline Relacje z nauczycielami & 163 & 84,5 & 22 & 78,6 & 185 & 83,7 \\
\hline Kraj pochodzenia & 153 & 79,3 & 24 & 85,7 & 177 & 80,1 \\
\hline Postępy w nauce & 157 & 81,3 & 20 & 71,4 & 177 & 80,1 \\
\hline Uczestnictwo w życiu klasy & 157 & 81,3 & 20 & 71,4 & 177 & 80,1 \\
\hline Długość pobytu w Polsce & 80 & 41,5 & 12 & 42,9 & 92 & 41,6 \\
\hline Status pobytu & 74 & 38,3 & 16 & 57,1 & 90 & 40,7 \\
\hline Relacje rodzinne & 76 & 39,4 & 12 & 42,9 & 88 & 39,8 \\
\hline Religia & 72 & 37,3 & 10 & 35,7 & 82 & 37,1 \\
\hline Oczekiwania edukacyjne & 68 & 35,2 & 10 & 35,7 & 78 & 35,3 \\
\hline Kultura & 58 & 30,1 & 10 & 35,7 & 68 & 30,8 \\
\hline Warunki bytowe & 56 & 29,0 & 10 & 35,7 & 66 & 29,9 \\
\hline Doświadczenia migracyjne & 40 & 20,7 & 6 & 21,4 & 46 & 20,8 \\
\hline Wykształcenie rodziców & 30 & 15,5 & 8 & 28,6 & 38 & 17,2 \\
\hline Doświadczenia szkolne & 28 & 14,5 & 6 & 21,4 & 34 & 15,4 \\
\hline
\end{tabular}

$\mathrm{N}^{*}$ - liczba nauczycieli, którzy udzielili odpowiedzi $=193, \mathrm{~N}^{* *}$ - liczba pedagogów, którzy udzielili odpowiedzi $=28$

Większość badanych (około 80\%) była zorientowana głównie w sytuacji dzieci cudzoziemskich $\mathrm{w}$ szkole (jakie miały relacje $\mathrm{z}$ nauczycielami i rówieśnikami, postępy w nauce, uczestnictwo w życiu klasy) oraz z jakiego kraju pochodziły. Znacznie mniej osób (około 40\%) orientowało się, jak długo dane dziecko przebywa w Polsce, jaki jest jego status pobytu, relacje rodzinne oraz wyznawana religia. Tylko $1 / 3$ respondentów interesowała się oczekiwaniami rodziny wobec edukacji, kulturą pochodzenia uczniów i warunkami bytowymi. Najmniejsze zainteresowanie przejawiali badani odnośnie doświadczenia migracyjnego (21\%), 
wykształcenia rodziców (17\%) i dotychczasowych doświadczeń szkolnych uczniów pochodzących z innych krajów (15\%).

Badani nauczyciele byli lepiej (i ogólnie najlepiej) zorientowani w postępach dzieci w nauce, relacjach $\mathrm{z}$ nauczycielami i zaangażowaniu uczniów w życie klasy, natomiast pedagodzy - $\mathrm{w}$ tym, $\mathrm{z}$ jakiego kraju pochodzą uczniowie cudzoziemscy. Wyższy stopień orientacji prezentowali także pedagodzy odnośnie statusu pobytu uczniów, ich relacji z rodziną, warunków bytowych i wykształcenia rodziców, niemniej jednak tylko co trzeci badany z tej grupy deklarował wiedzę w tym zakresie.

Na podstawie uzyskanych danych możemy stwierdzić, że większość zarówno nauczycieli, jak i pedagogów nie przywiązywała wagi do znaczenia kultury, religii, doświadczeń migracyjnych, a nawet dotychczasowych doświadczeń edukacyjnych uczniów. Wygląda na to, że nie brali oni pod uwagę problemów towarzyszących migracjom międzykulturowym i obciążeń psychofizycznych swoich podopiecznych, a jedynie interesowali się aktualnym funkcjonowaniem uczniów cudzoziemskich w szkole, co było najłatwiej dostępne w codziennej obserwacji.

Trudno jednoznacznie określić, czy wynika to $\mathrm{z}$ ogólnego podejścia do wszystkich uczniów, czy z niewiedzy o dodatkowych obciążeniach towarzyszących dzieciom migrującym.

Biorąc pod uwagę wyniki badań dotyczące wiedzy respondentów o specyfice problemów uczniów imigrantów i wcześniejsze stwierdzenia braku rozwijania kompetencji międzykulturowych kadry pedagogicznej w instytucjach kształcących i doskonalących nauczycieli i pedagogów szkolnych, można pokusić się o stwierdzenie, że wynika to raczej z nieznajomości problemu.

Wiedza badanych na temat specyficznych problemów uchodźców i imigrantów

Zakres wiedzy niezbędnej dla planowania i prowadzenia pracy dydaktyczno-wychowawczej z uczniami cudzoziemskimi jest bardziej rozległy niż w odniesieniu do uczniów polskich. Chcąc prawidłowo zdiagnozować sytuację dziecka cudzoziemskiego, należy mieć świadomość jego problemów adaptacyjnych (szok kulturowy, nieznajomość języka, poczucie niepewności i zagrożenia, brak kompetencji społecznych i kulturowych, poczucie wyizolowania, zależność od innych) doświadczanych przez wszystkich imigrantów oraz wiedza dotycząca szczególnych doświadczeń uchodźców.

Diagnozując wiedzę respondentów, zapytaliśmy ich o problemy doświadczane przez uczniów cudzoziemskich uczęszczających do polskich szkół oraz różnice pomiędzy problemami doświadczanymi przez dzieci uchodźcze i imigranckie (tab. 3). 
Tabela 3. Wiedza badanych na temat specyficznych problemów dzieci cudzoziemskich uczęszczających do polskiej szkoły. Źródło: opracowanie własne

\begin{tabular}{|c|c|c|c|c|c|c|}
\hline \multirow{3}{*}{$\begin{array}{l}\text { Czy dzieci cudzoziemców uczęszczające } \\
\text { do polskiej szkoły mają jakieś specyficzne } \\
\text { problemy? }\end{array}$} & \multicolumn{4}{|c|}{ Stanowisko } & \multirow{2}{*}{\multicolumn{2}{|c|}{ Ogółem }} \\
\hline & \multicolumn{2}{|c|}{ nauczyciel } & \multicolumn{2}{|c|}{ pedagog } & & \\
\hline & {$[\mathrm{N}]^{*}$} & [\%] & {$[\mathrm{N}]^{* *}$} & [\%] & {$[\mathrm{N}]$} & [\%] \\
\hline Tak ( jakie?) & 137 & 71,0 & 26 & 92,9 & 163 & 73,7 \\
\hline Nie & 26 & 13,5 & 2 & 7,1 & 28 & 12,7 \\
\hline Nie wiem & 30 & 15,5 & - & - & 30 & 13,6 \\
\hline Ogółem & 193 & 100,0 & 28 & 100,0 & 221 & 100,0 \\
\hline
\end{tabular}

$\mathrm{N}^{*}$ - liczba nauczycieli, którzy udzielili odpowiedzi, $\mathrm{N}^{* *}$ - liczba pedagogów, którzy udzielili odpowiedzi

Blisko trzy czwarte badanych (73,7\% wszystkich wskazań, w tym: pedagodzy 92,9\%, nauczyciele 71\%) miało świadomość istnienia specyficznych problemów towarzyszących migracji międzykulturowej. Stosunkowo lepiej poinformowani wydawali się pedagodzy szkolni, spośród których żaden nie zadeklarował braku orientacji w danym zakresie (czynił to ponad co dziesiąty nauczyciel). Wśród respondentów były osoby, które stwierdzały, że dzieci cudzoziemskie nie doświadczają żadnych specyficznych problemów powiązanych z migracjami międzykulturowymi. Stanowisko takie prawie dwukrotnie częściej zajmowali nauczyciele (13,5\%), niż pedagodzy $(7,1 \%)$.

W odpowiedzi na prośbę o wskazanie konkretnego problemu wymieniano jednak tylko brak znajomości języka polskiego. Żaden z badanych nie wspomniał o innych problemach towarzyszących akulturacji i wrastaniu w środowisko nowego kraju.

Badani nauczyciele i pedagodzy prezentowali także słabą zdolność do różnicowania problemów dzieci uchodźczych i imigranckich (tab. 4).

Tabela 4. Wiedza badanych na temat różnicy pomiędzy uchodźcami a imigrantami. Źródło: opracowanie własne

\begin{tabular}{|c|c|c|c|c|c|c|}
\hline \multirow{3}{*}{$\begin{array}{l}\text { Czy dzieci uchodźców lub dzieci- } \\
\text {-uchodźcy mają problemy różniące } \\
\text { ich od dzieci imigrantów? }\end{array}$} & \multicolumn{4}{|c|}{ Stanowisko } & \multirow{2}{*}{\multicolumn{2}{|c|}{ Ogółem }} \\
\hline & \multicolumn{2}{|c|}{ nauczyciel } & \multicolumn{2}{|c|}{ pedagog } & & \\
\hline & {$[\mathrm{N}]^{*}$} & [\%] & {$[\mathrm{N}]^{* *}$} & [\%] & {$[\mathrm{N}]$} & [\%] \\
\hline Tak (jakie?) & 55 & 28,5 & 12 & 42,9 & 67 & 30,3 \\
\hline $\mathrm{Nie}$ & 3 & 1,5 & 4 & 14,2 & 7 & 3,2 \\
\hline Nie wiem & 135 & 70,0 & 12 & 42,9 & 147 & 66,5 \\
\hline Ogółem & 193 & 100,0 & 28 & 100,0 & 221 & 100,0 \\
\hline
\end{tabular}

$\mathrm{N}^{\star}$ - liczba nauczycieli, którzy udzielili odpowiedzi, $\mathrm{N}^{\star *}$ - liczba pedagogów, którzy udzielili odpowiedzi 
Dzieci uchodźcze i imigranckie, mimo wspólnych problemów towarzyszących akulturacji, doświadczają także problemów specyficznych, wynikających z odmiennych okoliczności migracji oraz towarzyszących temu doświadczeń i przeżyć emocjonalnych. Fakt ten nie wydawał się oczywisty dla większości badanych (66,5\%), którzy zadeklarowali brak wiedzy (w tym 70\% nauczycieli i 42,9\% pedagogów). Pomimo deklaracji lepszej orientacji pedagogów w tym zakresie w tej grupie wyższy był odsetek deklarujących brak istnienia specyfiki problemów uchodźców i imigrantów (14,2\% pedagogów i 1,5\% nauczycieli). Jedynie mniej niż co trzecia badana osoba miała świadomość istnienia owej specyfiki. Relatywnie częściej orientację taką deklarowali pedagodzy szkolni (42,9\%) niż nauczyciele $(28,5 \%)$.

Respondenci, wymieniając problemy charakterystyczne dla dzieci uchodźczych, wskazywali na specyfikę reakcji na traumatyczne doświadczenia będące udziałem uchodźców (wyrażane m.in., stwierdzeniami „prawdopodobnie trudniej im ze względu na doświadczenie zespołu stresu pourazowego”, „mają poczucie zagrożenia bezpieczeństwa”), niestabilność statusu i sytuacji („częste zmiany pobytu i szkoły, tymczasowość sytuacji życiowej”, „dzieci «rodzice» uchodźców nie traktują naszego kraju jako docelowego miejsca pobytu, więc szkołę traktują mniej obowiązkowo”), większe problemy z dostosowaniem się do norm i standardów życia społecznego („Czeczeńcy niechętnie chodzili do szkoły”, „wykazywali większe problemy integracji z kolegami i koleżankami, dopasowywanie się do zasad i norm postępowania w szkole”) oraz większe problemy materialne.

Czasami podkreślano także większą złożoność i wielowymiarowość ich sytuacji, nakładające się problemy emocjonalne i bytowe, niewyjaśniony jeszcze formalny status, poczucie tymczasowości, strach, lęk, wycofanie.

Powyższe wyniki pokazują, że część osób orientuje się, jakich problemów doświadczają dzieci uchodźcze, jednak znaczny odsetek respondentów ma znikomą wiedzę na ten temat. Szczególnie niepokojąca jest słaba orientacja pedagogów w tym zakresie, bo przecież ich zadaniem jest wspieranie uczniów z problemami, a badania pokazują, że $3 / 5$ nie ma pojęcia o potencjalnych problemach dzieci uchodźców.

\section{Podsumowanie}

Reasumując: badane osoby dostrzegały znaczenie czynników kulturowych dla kształtowania się kompetencji uczniów, ale prezentowali tendencję do niedoceniania roli czynników sytuacyjnych, doświadczeń migracyjnych i różnic indywi- 
dualnych, co jest niepokojące zwłaszcza w odniesieniu do pedagogów szkolnych, $\mathrm{z}$ założenia przygotowywanych do indywidualnej pracy z każdym uczniem.

Niezbyt wysoka była również wiedza respondentów dotycząca problemów towarzyszących migracjom. Niektórzy w ogóle nie uświadamiali sobie specyfiki tego rodzaju doświadczenia, a pozostali dostrzegali przede wszystkim problemy językowe, wykazując brak wiedzy co do innych i bardziej istotnych problemów, jak na przykład akulturacyjnych. Ponad połowa badanych nie zdawała sobie także sprawy ze specyfiki traumatycznych doświadczeń uchodźstwa, a nawet byli tacy, którzy negowali istnienie takich doświadczeń. Nie zdając sobie sprawy z takich zjawisk i problemów uczniów cudzoziemskich, nie mieli oni dostatecznej świadomości potrzeby diagnozowania i dostosowywania metod pracy do specyfiki uczniów oraz podejmowania odpowiedniego wsparcia.

Ogólne wyzwanie dla edukacji i kadry pedagogicznej to przede wszystkim poszanowanie inności, poszukiwanie płaszczyzn pozytywnej komunikacji, tolerancja i zrozumienie pomiędzy osobami reprezentującymi odmienne kultury oraz niedopuszczanie do dyskryminacji jakichkolwiek grup.

Jednym z elementów, który wpływa na sposób traktowania ucznia i podejmowane działania wobec niego, jest wiedza związana $\mathrm{z}$ jego pochodzeniem, potencjałem intelektualnym, problemami i potrzebami.

Należy dostosować pracę szkoły do kulturowej heterogeniczności uczniów poprzez uaktualnianie programów kształcenia, metod pracy, organizacji pracy z uczniami oraz skuteczne indywidualne wsparcie (wypracowanie systemu wczesnej diagnozy i interwencji), a także rozwijać kompetencje nauczycieli, pedagogów, kadry zarządzającej i psychologów, do wspierania uczniów pochodzących z innych krajów i promowania wzajemnego zrozumienia między wszystkimi uczniami, aby kształtować właściwe postawy wobec innych, stosowania podejścia międzykulturowego czyli uczenia się dialogu międzykulturowego poprzez edukację. Aby to realizować, należy wprowadzić do programów kształcenia nauczycieli i pedagogów szkolnych obligatoryjne zajęcia kształtujące kompetencje pracy z uczniami cudzoziemskimi i ich rodzicami.

Warto również zastanowić się nad zmianą formuły zawodowej pedagoga szkolnego, który nie powinien ograniczać się do działań o charakterze korekcyjnym i terapeutycznym, lecz także (a może przede wszystkim) realizować zadania związane ze wspomaganiem społecznego rozwoju ucznia oraz profilaktyką nieprzystosowania i wykluczenia społecznego, adaptując metody pracy streetworkera (pedagog wychodzący do uczniów poza ściany swego gabinetu, zamiast czekający, aż uczeń zostanie do niego skierowany). 


\section{Literatura}

Badowska M. (2011). Migracje międzykulturowe a przestrzeń polskiej szkoty. [W:] K. Najder-Stefaniak, J. Wyleżałek, M. Cywińska (red.). Homo viator w świecie spotkania kultur. Warszawa.

Borzykowski K., Grzymała-Moszczyńska H. (red.). (2013). Wybrane zagadnienia diagnozy psychologicznej dzieci i młodzieży w kontekście wielokulturowości i wielojęzyczności. Warszawa.

Boski P. (2009). Kulturowe ramy zachowań społecznych. Warszawa.

Grzymała-Moszczyńska H. (1998). Sytuacja uchodźców w literaturze psychologicznej. [W:] H. Grzymała-Moszczyńska, E. Nowicka (red.). Goście i gospodarze. Kraków.

Grzymała-Moszczyńska H. (2000). Uchodźcy. Podręcznik dla osób pracujących z uchodźcami. Kraków.

Gundara J. (2000). Interculturalism, Education and Inclusion. London.

Heckmann F. (2008). Education and Migration, strategies for integrating migrant children in European schools and societies. A synthesis of research findings for policy-makers. http://www.nesse.fr/ nesse/activities/reports/activities/reports/education-and-migration-pdf [dostęp: 14.09.2012].

Januszewska E. (2010). Dziecko czeczeńskie Dziecko czeczeńskie w Polsce. Między trauma wojenna, a doświadczeniem uchodźctwa. Toruń.

Komisja Europejska. (2005). Kompetencje kluczowe. Warszawa.

Komisja Europejska. (2008), Zielona Księga Migracja i mobilność: wyzwania i szanse dla wspólnotowych systemów edukacyjnych, Komisja Europejska COM 423 final.

Krzywicka L. (2007). Przemoc $w$ rodzinie - specyfika pracy socjalnej z ofiarami przemocy. [W:] S. Pawlas-Czyż. Praca socjalna wobec współczesnych problemów społecznych. Toruń.

Leseman P. (2010) Wpływ wysokiej jakości edukacji i opieki na rozwój małych dzieci: przegląd literatury. [W:] Wczesna edukacja i opieka nad dzieckiem w Europie: zmniejszanie nierówności społecznych i kulturowych. Warszawa.

Lis-Turlejska M. (1998). Traumatyczny stres. Koncepcje i badania. Warszawa.

Mittler P. (2000). Working Towards Inclusive Education: Social Contexts. London.

Przetacznik-Gierowska M., Włodarski Z. (1994). Psychologia wychowawcza. Warszawa.

Rabczuk W. (2007). Polityka edukacyjna Unii Europejskiej. Nowe konteksty. Warszawa.

Rezolucja Parlamentu Europejskiego z dnia 2 kwietnia 2009 r. w sprawie kształcenia dzieci imigrantów, (Dz.U.UE C z dnia 27 maja 2010 r.).

Sielatycki M., Kompetencje nauczyciela w Unii Europejskiej, http://www.cen.uni.wroc.pl/Pliki/ 13.pdf [dostęp: 20.03.2014].

\section{Cultural Diversity of Students is a Challenge for Contemporary of the School}

\section{Summary}

The surveyed people perceived importance of cultural factors for the development of the competencies of students, but presented a tendency to underestimate the role of situational factors, migration experience and individual differences. It was also not very high knowledge of the respond- 
ents concerning the problems associated with migration. Some even did not realize the specifics of this kind of experience, while others perceived above all, language problems, demonstrating a lack of knowledge about other important issues, such as problems of acculturation. More than half of those surveyed did not realize also the case with the specifics of traumatic experiences of refugees. Unaware of these phenomena and problems of foreign students, they did not have sufficient awareness of the need to diagnose and adapt working methods to the specific students, and to take appropriate support.

School should be adapted to the cultural heterogeneity of the students by updating curricula, working methods, organization of work with students and develop a system of effective individualized support of pupils from other countries. We need to develop the skills of teachers, educators, managers and psychologists, to support this category of students through education and implementation of intercultural learning, acceptance of diversity, understanding and dialogue.

To achieve this, we need to introduce into education programs for teachers and school counselors, items affecting the competence to work with migrant students and their parents. 